\title{
Research on the Quantitative Behavior Assessment of Undergraduate Students: A Case Study of Bohai University
}

\author{
Xiaoshu Wang ${ }^{\mathrm{a}^{*}}$ and Le Wang ${ }^{\mathrm{b}}$ \\ Bohai University, Jinzhou, Liaoning, China \\ a49718990@qq.com, blewang1982@163.com
}

\begin{abstract}
Keywords: Behavior assessment; Undergraduate students; Positive behavior; Negative behavior; Bohai University
\end{abstract}

\begin{abstract}
Undergraduate students should have good moral character and behavior habits, Bohai University had design a quantitative behavior assessment system for undergraduate students. The assessment purpose is to make the undergraduate students to learn to behave, learn to work, learn to cooperate, and learn to survive. Each student's starting score is 60 points, then according to the behavior of the students, plus or minus points. Positive behavior including acting as a student leader, participate in public welfare activities, actively participate in school activities, put forward reasonable suggestions, winning in academic competitions, and receive an honorary title. Negative behavior including affect public environment and order, affect public safety, uncivilized behavior that affects other people, and violate school regulations and disciplines. The students' behavior assessment office is responsible for recording scores, before graduation, if the total score of behavioral assessment is still over 60 points, the student can get 2 credits; otherwise, students cannot graduate on time.
\end{abstract}

\section{Introduction}

In the "Administrative Regulations for Common Institutions of Higher Education" issued by Ministry of Education of the People's Republic of China, undergraduate students should foster the conception of patriotism with the spirit of unity, peace loving, hardworking and brave, unremitting self-improvement; should abide by the constitution, laws, regulations and the code of ethics, good moral character and behavior habits, comply with the code of conduct for college students, comply with the school management system; should study hard, have the courage to explore, actively practice, and strive to master the modern scientific and cultural knowledge and professional skills; should actively exercise, and have a healthy physique. ${ }^{[1-10]}$

In order to achieve the above objectives, Bohai University had design a quantitative behavior assessment system for undergraduate students, including assessment purpose, principles and content, assessment scores and implementation, organizational structure, positive behavior, negative behavior and the use of result.

\section{Assessment Purpose, Principles and Content}

Assessment Purpose. Through the implementation of the evaluation of all the undergraduate students, make them to learn to behave, learn to work, learn to cooperate, and learn to survive, so as to achieve the purpose of regulating the campus order and improving the overall quality of students, training qualified talents.

Assessment Principles. Follow the principles of fair, just and open, combining quantitative assessment and qualitative assessment together, combining process assessment and result assessment together, ensure the scientific and rational reflection of the actual quality of students.

Assessment Scope and Content. The object of assessment is all the undergraduate students, mainly focus on students' performance of ideological and political beliefs, moral cultivation, behavior, social contribution, comprehensive skills and other aspects. 


\section{Assessment Scores and Implementation}

Each student's starting score is 60 points, according to the "Bohai University Students Behavior Assessment standards" and "Bohai University Provisions on Disciplinary Measures for Students", plus or minus points, and summary at the end of each semester. Before graduation, if the total score of behavioral assessment is still over 60 points, the student can get 2 credits; otherwise, students cannot graduate on time.

Bohai University set up a leading group for behavioral assessment, the group leader is the vice president in charge of student affairs, and the group members include the director of student development and affairs, the director of student safety and life services, and director of the academic affairs office. The leading group has two offices: supervision office and students' behavior assessment office. Supervision office is in charge of assessment guidance and supervision, accepting students' complaints. Students' behavior assessment office is responsible for recording scores; the score is calculated based on the materials submitted by each school.

\section{Positive Behavior}

Positive behavior including acting as student leader, participate in public welfare activities, actively participate in school activities, put forward reasonable suggestions, winning in academic competitions, and receive an honorary title. The plus score standards are listed in Table 1.

Table 1 The plus score standards of positive behavior

\begin{tabular}{|c|c|c|c|}
\hline Categories & \multicolumn{2}{|l|}{ Items } & Score \\
\hline \multirow{22}{*}{$\begin{array}{l}\text { Acting as a } \\
\text { student leader }\end{array}$} & \multirow{2}{*}{$\begin{array}{l}\text { University or school } \\
\text { youth league }\end{array}$} & Secretary & +20 \\
\hline & & Department director & +15 \\
\hline & \multirow{3}{*}{ Student union } & President and vice president & +20 \\
\hline & & Department director & +15 \\
\hline & & Vice department director & +10 \\
\hline & \multirow{3}{*}{$\begin{array}{l}\text { Student self discipline } \\
\text { committee }\end{array}$} & President and vice president & +20 \\
\hline & & Department director & +15 \\
\hline & & Vice department director & +10 \\
\hline & \multirow{3}{*}{$\begin{array}{l}\text { Federation of student } \\
\text { associations }\end{array}$} & President and vice president & +20 \\
\hline & & Department director & +15 \\
\hline & & Department director & +10 \\
\hline & \multirow{3}{*}{$\begin{array}{l}\text { Five star student } \\
\text { associations }\end{array}$} & Chairman & +20 \\
\hline & & Vice chairman & +15 \\
\hline & & Department director & +10 \\
\hline & \multirow{3}{*}{$\begin{array}{l}\text { Three or four star } \\
\text { student associations }\end{array}$} & Chairman & +15 \\
\hline & & Vice chairman & +10 \\
\hline & & Department director & +5 \\
\hline & \multirow{2}{*}{ Class cadre } & Excellent class cadre & +15 \\
\hline & & Other class cadre & +10 \\
\hline & \multirow{3}{*}{ Dormitory leader } & President of dormitory committee & +20 \\
\hline & & Floor leader & +15 \\
\hline & & Dormitory leader & +5 \\
\hline \multirow{6}{*}{$\begin{array}{l}\text { Participate in } \\
\text { public welfare } \\
\text { activities }\end{array}$} & \multicolumn{2}{|c|}{ Volunteer for long term international activities } & +30 \\
\hline & \multicolumn{2}{|c|}{ Volunteer for short term international activities } & +20 \\
\hline & \multicolumn{2}{|c|}{ Volunteer for national activities } & +20 \\
\hline & \multicolumn{2}{|c|}{ Volunteer for provincial activities } & +10 \\
\hline & \multicolumn{2}{|c|}{ Volunteer teacher over 10 days } & +10 \\
\hline & \multicolumn{2}{|c|}{ Volunteer for municipal activities } & +2 \\
\hline
\end{tabular}


Table 1 cont.

\begin{tabular}{|c|c|c|c|}
\hline \multirow{5}{*}{$\begin{array}{l}\text { Actively } \\
\text { participate in } \\
\text { school activities }\end{array}$} & \multicolumn{2}{|c|}{ Perform well in routine examinations and evaluations } & +3 \\
\hline & \multicolumn{2}{|c|}{ Plan, organize, perform, or serve in a school activity } & +2 \\
\hline & \multicolumn{2}{|c|}{ Participate in academic competition but didn't win } & +2 \\
\hline & \multicolumn{2}{|c|}{ Volunteer service every 5 hours } & +2 \\
\hline & \multicolumn{2}{|c|}{ Audience in academic reports and educational activities } & +1 \\
\hline \multirow{3}{*}{$\begin{array}{l}\text { Put forward } \\
\text { suggestions }\end{array}$} & \multicolumn{2}{|c|}{ Put forward suggestions for the development of the university } & +5 \\
\hline & \multicolumn{2}{|c|}{ Timely reporting of security risks } & +5 \\
\hline & \multicolumn{2}{|c|}{ Help other students cope with emergencies } & +5 \\
\hline \multirow{12}{*}{$\begin{array}{l}\text { Winning in } \\
\text { academic } \\
\text { competitions }\end{array}$} & \multirow{4}{*}{ National level } & Grand prize & +50 \\
\hline & & First prize & +40 \\
\hline & & Second prize & +35 \\
\hline & & Third prize & +30 \\
\hline & \multirow{4}{*}{ Provincial level } & Grand prize & +30 \\
\hline & & First prize & +20 \\
\hline & & Second prize & +15 \\
\hline & & Third prize & +8 \\
\hline & \multirow{4}{*}{ University level } & Grand prize & +8 \\
\hline & & First prize & +6 \\
\hline & & Second prize & +4 \\
\hline & & Third prize & +2 \\
\hline \multirow{9}{*}{$\begin{array}{l}\text { Receive an } \\
\text { honorary title }\end{array}$} & \multirow{3}{*}{ Personal honor } & National level & +50 \\
\hline & & Provincial level & +30 \\
\hline & & University level & +8 \\
\hline & \multirow{3}{*}{$\begin{array}{l}\text { Class honor for } \\
\text { class committee } \\
\text { member }\end{array}$} & National level & +40 \\
\hline & & Provincial level & +20 \\
\hline & & University level & +6 \\
\hline & \multirow{3}{*}{$\begin{array}{l}\text { Class honor for } \\
\text { classmates }\end{array}$} & National level & +20 \\
\hline & & Provincial level & +10 \\
\hline & & University level & +3 \\
\hline
\end{tabular}

\section{Negative Behavior}

Negative behavior including affect public environment and order, affect public safety, uncivilized behavior that affects other people, and violate school regulations and disciplines. The minus score standards are listed in Table 2.

Table 2 The minus score standards of negative behavior

\begin{tabular}{|l|l|c|}
\hline Categories & Items & Score \\
\hline & $\begin{array}{l}\text { 1. Painting on the wall, corridor } \\
\text { 2. Trample on the lawn, broken flowers } \\
\text { 3. Loud laughter, play sports, make trouble, etc. affect others } \\
\text { 4. Late and leave early in lectures and other activities } \\
\text { 5. Spitting, chewing gum, littering, throwing sewage } \\
\text { environment } \\
\text { and order }\end{array}$ & $\begin{array}{l}\text { 6. Smoking in non-smoking area } \\
\text { 7. Bring pets to the campus or to keep pets } \\
\text { 8. Do not turn off the tap after use of water } \\
\text { 9. Waste food } \\
\text { 10. Minor damage to public facilities and equipment } \\
\text { 11. Engage in profitable activities in public areas } \\
\text { 12. Dormitory clean check not qualified }\end{array}$ \\
\hline Affect public & 1. Finally leave the room without turning off the power & \\
\end{tabular}


Table 2 cont.

\begin{tabular}{|c|c|c|c|}
\hline safety & \multicolumn{2}{|c|}{$\begin{array}{l}\text { 2. Unauthorized removal of public facilities and equipment } \\
\text { 3. Stowage of debris and vehicles in the lobby, corridors, fire } \\
\text { exits, bedroom and balcony } \\
\text { 4. Playing, fishing in the lake, throwing debris into the lake or } \\
\text { walking on the ice } \\
\text { 5. Climb the balcony, railings and attic, throwing objects from } \\
\text { high buildings } \\
\text { 6. Touch the building fire alarm button } \\
\text { 7. Change the door lock, lend the bedroom key to other people, } \\
\text { exchange bedroom or bed without permission } \\
\text { 8. Unsafe riding, chasing in driveways and dangerous areas } \\
\text { 9. Lend entrance guard card to other people } \\
\text { 10. Setting off fireworks and firecrackers on campus }\end{array}$} & \\
\hline $\begin{array}{l}\text { Uncivilized } \\
\text { behavior that } \\
\text { affects other } \\
\text { people }\end{array}$ & \multicolumn{2}{|c|}{$\begin{array}{l}\text { 1. Do not respect others, discriminate or insult others } \\
\text { 2. Do not respect the privacy of others, do not cherish the work } \\
\text { of others } \\
\text { 3. Do not use civilized language, slang and profanity } \\
\text { 4. Uncivilized manners, do not work with the staff } \\
\text { 5. Do not abide by the network ethics, indulge in online games } \\
\text { 6. Dishonesty, influence unity } \\
\text { 7. Do not abide by the apartment schedule, affect others rest } \\
\text { 8. Entanglement or harassment of others, affect the normal } \\
\text { learning and life of others } \\
\text { 9. Canvassing votes in the elections and awards activities } \\
\text { 10. Indecent dress or weird hairstyle in public }\end{array}$} & -2 \\
\hline $\begin{array}{l}\text { Violate school } \\
\text { regulations and } \\
\text { disciplines. }\end{array}$ & $\begin{array}{l}\text { 1. Violation of the Constitution } \\
\text { 2. Violation of state laws and regulations } \\
\text { 3. Embezzlement of public or private } \\
\text { property } \\
\text { 4. Buying and selling stolen goods } \\
\text { 5. Smuggling, illegal reselling } \\
\text { 6. Gambling or gambling in disguise } \\
\text { 7. Disrupting school and social order } \\
\text { 8. Violation of apartment management } \\
\text { regulations } \\
\text { 9. Discipline and cheating in the exam } \\
\text { 10. Violation of personal rights of others }\end{array}$ & $\begin{array}{l}\text { Warning: -10 } \\
\text { Serious warning: } \\
\text { Record a demerit: } \\
\text { Disciplinary proba }\end{array}$ & $\begin{array}{l}0 \\
\text { n: }-50\end{array}$ \\
\hline
\end{tabular}

If a student seriously violated the university discipline, the student will be expelled from Bohai University, so the maximum penalty in quantitative behavior assessment is disciplinary probation.

\section{The Result of Quantitative Behavior Assessment}

This quantitative behavior assessment in Bohai University is start in 2015, this paper takes the grade 2013 of School of Management as an example. There are 669 undergraduate students in grade 2013, major in accounting, marketing, business management, logistics management, excellent management, and banking institute. At the end of 2015 spring semester, only 11 students' behavior score are less than 60 , only accounted for $1.64 \%$ of all the students. The proportion of students who violate discipline is greatly reduced compared with the past. Detailed distribution of student scores of 2015 spring semester is listed in Table 3. 
Table 3 Distribution of scores of grade 2013 students in School of Management (\%)

\begin{tabular}{|l|c|c|c|c|c|c|c|}
\hline Major & $>80$ & $71-80$ & $61-70$ & 60 & $<60$ & $\begin{array}{c}\text { Highest } \\
\text { Score }\end{array}$ & $\begin{array}{c}\text { Lowest } \\
\text { Score }\end{array}$ \\
\hline Finance & 4.82 & 12.05 & 40.96 & 42.17 & 0 & 90 & 60 \\
\hline Accounting & 5.09 & 15.28 & 43.98 & 33.33 & 2.31 & 89 & 56 \\
\hline Marketing & 16.67 & 17.65 & 31.37 & 33.33 & 0.98 & 156 & 50 \\
\hline Business Management & 16.49 & 13.40 & 38.14 & 28.87 & 3.09 & 94 & 58 \\
\hline Logistics management & 12.82 & 17.95 & 34.19 & 33.33 & 1.71 & 114 & 58 \\
\hline Excellent Management & 5.56 & 14.81 & 27.78 & 51.85 & 0 & 97 & 60 \\
\hline
\end{tabular}

\section{Conclusion}

This paper introduces the quantitative behavior assessment system for undergraduate students in Bohai University. Each student's starting score is 60 points, then according to the behavior of the students, plus or minus points. Positive behavior including acting as a student leader, participate in public welfare activities, actively participate in school activities, put forward reasonable suggestions, winning in academic competitions, and receive an honorary title. Negative behavior including affect public environment and order, affect public safety, uncivilized behavior that affects other people, and violate school regulations and disciplines. After one semester's practice, the proportion of students who violate discipline is greatly reduced.

\section{Acknowledgements}

This research was supported by the University Basic Scientific Research Foundation of Department of Education of Liaoning Province (WY2016007) and the Teaching Reform Research Project of Bohai University (BDJG-14-QN-C-002).

\section{References}

[1] W. Fang: Journal of Studies in International Education, Vol.16 (2012) No.2, p.5-23.

[2] H. Xin: Science, Vol.337 (2012) No.6095, p.634-635.

[3] X. Li, O. Li: Journal of Neurochemistry, Vol.135 (2015) No.2, p.287-300.

[4] G. Prathap: Current Science, Vol.102 (2012) No.6, p.827.

[5] L. Zhang, G. Qi, A.R. Vernooy: Movement Disorders, (2014) No.29, p.S35-S36.

[6] E. Fang, C. Kim: Corrosion Science, Vol.15 (2013) No.6-12, p. 767-773.

[7] K. Powell: Nature, Vol.504 (2013) No.7480, p.471-473.

[8] D. Edwards, V. Eva: Prenatal Diagnosis, Vol.11 (2012) No.8, p.563-567.

[9] J. Muñoz Cantero, M.D. Matovásquez: Soil Biology \& Biochemistry, Vol.78 (2014) No.78, p.243-254.

[10] X Jiang: Arthritis Research \& Therapy, Vol.17 (2015) No.1, p.1-9. 